\title{
Masszív pulmonalis embolia és thromboemboliás kórképek intervenciós radiológiai kezelése
}

\author{
Battyáni István dr. ${ }^{1}$ - Dósa Edit dr. ${ }^{2}$ - Harmat Zoltán dr. ${ }^{1}$ \\ ${ }^{1}$ Pécsi Tudományegyetem, Klinikai Központ, Általános Orvostudományi Kar, Radiológiai Klinika, Pécs \\ ${ }^{2}$ Semmelweis Egyetem, Általános Orvostudományi Kar, Szív- és Érgyógyászati Klinika, Érsebészeti Tanszék, \\ Budapest
}

\begin{abstract}
A szerzők a vascularis intervenciós radiológiának a vénás rendszer betegségeiben alkalmazott intervenciós radiológiai módszereit mutatják be. A vénás betegségek kezeletlenül vagy nem megfelelő módon kezelve a beteg életét veszélyeztetik és krónikus megbetegedések, vénás elégtelenség kialakulásához vezethetnek, ami a betegek számára tartós életminőség-romlást és visszatérő kezelést igénylő klinikai panaszokat okoz. Az intervenciós radiológia számos módszerrel rendelkezik, amely időben alkalmazva gyors és teljes gyógyulást eredményezhet. A szerzők ezeket a módszereket foglalják össze, remélve, hogy az intervenciós radiológiai centrumok létrehozásával a módszerek széles tömegek számára hozzáférhetővé válnak és beilleszkednek a napi rutin-betegellátásba. A vénás betegségek gyakorisága és az életminőséget jelentősen befolyásoló hatása miatt a szerzők szeretnék az érdeklődést felkelteni az intervenciós radiológiai módszerek iránt és a figyelmet ráirányítani a modern terápiás lehetőségekre. Orv. Hetil., 2015, 156(17), 674679.
\end{abstract}

Kulcsszavak: mélyvénás thrombosis, thrombolysis, szelektív thrombolysis, vénás stentelés, pulmonalis embolia, mechanikus thrombusdarabolás

\section{Interventional radiological treatment of extensive pulmonary embolism and thromboembolic diseases}

\begin{abstract}
The authors discuss interventional radiological methods in the field of vascular interventions applied in venous system diseases. Venous diseases can be lifethreatening without appropriate treatment and can lead to chronic venous diseases and venous insufficiency which result in long lasting life quality destruction. In addition, recurrent clinical symptoms are require additional treatments. Interventional radiology has several methods that can provide fast and complete recovery if applied in time. The authors summarize these methods hoping that they will be available for a wide range of patients through the establishment of Interventional Radiological Centres and will be a part of the daily routine of patient care. Regarding the frequency of venous diseases and its influance on life quality the authors would like to draw attention to interventional radiological techniques and modern therapeutic possibilities.
\end{abstract}

Keywords: deep vein thrombosis, thrombolysis, selective thrombolysis, venous stenting, pulmonary embolism, mechanical thrombus fragmentation

Battyáni, I., Dósa, E., Harmat Z. [Interventional radiological treatment of extensive pulmonary embolism and thromboembolic diseases]. Orv. Hetil., 2015, 156(17), 674-679.

(Beérkezett: 2015. február 6.; elfogadva: 2015. február 21.)

\section{Rövidítések}

CTPA = komputertomográfiás pulmonalis angiográfia; EKOS = ultrahangos percutan mechanikus thrombectomia; $\mathrm{IU}=$ nemzetközi egység; MRI = mágneses rezonanciás vizsgálat $\mathrm{PE}=$ pulmonalis embolia; $\mathrm{PTD}=$ percutan thrombectomi- ás eszköz; PTX = pneumothorax; r-tPA = rekombináns szöveti plazminogén aktivátor; sc. = subcutan; $\mathrm{SK}=$ sztreptokináz; SP54 = sodium pentosanpolysulfate; TIPS $=$ transjugularis intrahepaticus portoszisztémás sönt; $\mathrm{UK}=$ urokináz 
$\mathrm{Az}$ intervenciós radiológia vascularis csoportjában a vénás rendszert érintő beavatkozások sokrétűek és sok esetben életmentőek. A beavatkozások a vénás rendszerben a keringés helyreállítását célozzák vagy szövődmények kialakulását előzik meg. A vénás rendszerben alkalmazott fontosabb intervenciós radiológiai beavatkozások, amelyek hazánkban is elérhetők:

- masszív tüdőembólia intervenciós radiológiai invazív ellátása;

- akut alsó végtagi mélyvénás thrombosisok kezelése;

- mélyvénás szúküiletek kezelése (ballonos tágítása, stentelése);

- ideiglenes vagy végleges vena cava filter behelyezése;

- tágult, elégtelen vénás hálózatok embolisatiója (varicokele, tág haemorrhoidalis vénák embolisatiója, tágult gasztrikus, perigasztrikus vénás hálózatok embolisatiója);

- TIPS (transjugularis intrahepaticus portoszisztémás sönt) kialakítása;

- arteriovenosus malformációk embolisatiója;

- felületes vénák, visszértágulatok szklerotizációja, lézeres kezelése.

A felsorolás nem teljes, mert csak a nálunk is elérhető módszereket taglalja, de a kipróbálási fázisban lévő beavatkozásokat, mint például a vénabillentyư-beültetést, nem tartalmazza. A fentiek közül az első három módszert tárgyaljuk részletesebben.

\section{Masszív tüdőembólia (PE) intervenciós radiológiai invazív ellátása}

A mélyvénás thrombosis esetén gyakran 38-51\% körül alakult ki szövődményként tüdőembólia. A tüdőembólia 90\%-ban az alsó végtagi mélyvénás thrombosisok következménye. Közvetlen halálokként 10,8\%-ban fordult elő, ezért a sürgősségi esetekben gyakran találkozunk a tüdőembólia feltételezett diagnózisával. Napjainkban a szívbetegségben szenvedő és stroke-on átesett betegek effektív antithromboticus kezelésének köszönhetően a tüdőembólia okozta halálozás csökkenő tendenciát mutat. Hasonlóképpen a modern profilaktikus és terápiás kezelések $1 \%$ alá csökkentették a PE okozta halálozást a tumoros betegségben elhunytak esetén, és csökkentették a PE okozta halálozást az ischaemiás stroke-ban szenvedőknél [1, 2, 3]. A korábban használt Greenfield és Erbel-Meyer-féle súlyossági csoportba történő besorolást egy egyszerúbb klinikai besorolás váltotta fel, amely „nem masszív" (enyhe <20\%, mérsékelt 20-50\%) és „masszív" csoportra osztja a tüdőembóliát a súlyossági foka alapján. A korábbi egy lebenyre kiterjedő, körülbelül 30\%-os tüdőér-elzáródás helyett $50 \%$-os érelzáródásra változott a fibrinolízis és az intervenciós radiológiai beavatkozás indikációja [4]. Ennek megfelelően az intervenciós radiológiai beavatkozások indikációs körébe a masszív tüdőembóliák tartoznak. A súlyosság kérdésének megítélésében a dyspnoe, tachypnoe, syncope és mellkasi fájdalom, szisztémás vérnyomás csökkenésének együttes fennállása 95\%-ban valószínűsíti a súlyos tüdőembóliát, de számos egyéb vizsgálati eredmény könnyíti a megítélést, mint: klinikai score-ok (PISA-PED, Wells, Geneva-Wicki, módosított Geneva), EKG-eltérések $\left(\mathrm{S}_{1} \mathrm{Q}_{3}\right.$ komplex, P-pulmonale, jobbszár-blokk, R-tengely jobbra deviálása), Astrup-érték (alkalosis, alacsony $\mathrm{PaO}_{2}$ ), D-dimer-pozitivitás [5]. Differenciáldiagnosztikailag az aortadissectiótól és a myocardialis infarctustól történő elkülönítés a legfontosabb, de számos betegség keltheti tüdőembólia gyanúját, mint: pericarditis, PTX, pneumonia, pleuritis, vírusbetegség, asthma, izomfájdalom.

PE klinikai gyanúja esetén a CTPA (komputertomográfiás tüdő-angiográfia) adhat biztos diagnózist. Természetesen a lehetőségek függvényében izotópvizsgálatok, echokardiográfia, MRI és tüdő-angiográfia is alkalmazható. Egyszerűsége, hozzáférhetősége és a gyors lelethez jutás miatt a nemzetközi sürgősségi gyakorlatban az alacsony dózisú CTPA terjedt el. Napjainkban elsősorban a vénásan beadott nagy dózisú $100 \mathrm{mg}$ r-tPA-kezelést alkalmazzák egyszeri beadással vagy többszöri ismétléssel. A lehetőségek függvényében vagy költségcsökkentésként helyenként még alkalmazzák az ultramagas dózisú vagy hagyományos dózisú sztreptokináz- vagy urokinázkezelést. Az intervenciós radiológiai beavatkozások indikációja azok invazív jellege miatt kissé háttérbe szorult.

Intervenciós radiológiai beavatkozások indikációja PEben

- Masszív PE, legalább 50\%-os tüdőér-elzáródás.

- Kontraindikált szisztémás fibrinolízis súlyos masszív tüdőembóliával.

- Kontraindikált terápiás antikoaguláns kezelés súlyos masszív tüdőembóliával.

- Visszatérő krónikus súlyos embolisatio, krónikus PE.

Intervenciós radiológiai beavatkozások kontraindikációi PE-ben

- Aktív intracranialis vérzés.

- Koponyatrauma, -sérülés.

- Intracranialis vagy intraspinalis vérzés idegsebészeti mútét után.

- Intracranialis tumor vagy nagy arteriovenosus malformatio.

- Véralvadás súlyos zavara.

- Súlyos, nem kezelt hypertonia.

- Aktív gastrointestinalis vérzés.

Intervenciós radiológiai beavatkozások PE-ben

Mechanikus thrombusfragmentáció:

- Vezetődróttal, pigtail katéterrel, rotációs thrombusdarabolókkal (például Arrow-Trerotola PTD).

Thrombuseltávolítás, rheolyticus thrombectomia:

- Helix Clot Buster thrombectomiás eszköz,

- AngioJet rapid thrombectomiás rendszer,

- Cordis Hydrolyser hidrodinamikus thrombectomiás katéter, 
- Oasis thrombectomiás rendszer,

- Endowave rendszer.

Aspirációs thrombectomia:

- Greenfield pulmonalis embolectomiás katéter,

- Guiding-katétertechnika,

- szívókatéteres technika,

- Aspirex thrombusaspirációs eszköz,

- pulmonalis embolia revascularisatiója stenttel,

- ballonkatéteres rekanalizáció.

Szelektív thrombolysis:

- Szisztémás dózissal (javasolt amerikai és francia dózisok):

- $2000 \mathrm{IU} / \mathrm{kg} / \mathrm{h}, 4200 \mathrm{IU} / \mathrm{kg} / \mathrm{h}$ 24-12 órán át SK, $\mathrm{UK}$;

- r-tPA (100 mg/2 óra).

- Alacsony dózissal:

- SK 10 000-60 000 IU/h, UK 20 000-80 000 IU/h;

- r-tPA (1-5 mg/h).

- Kiegészítő kezelés: heparin iv. 800-1000 IU/h vagy sodium pentosanpolysulfate (SP54) sc. $2 \times 100 \mathrm{mg} /$ nap.

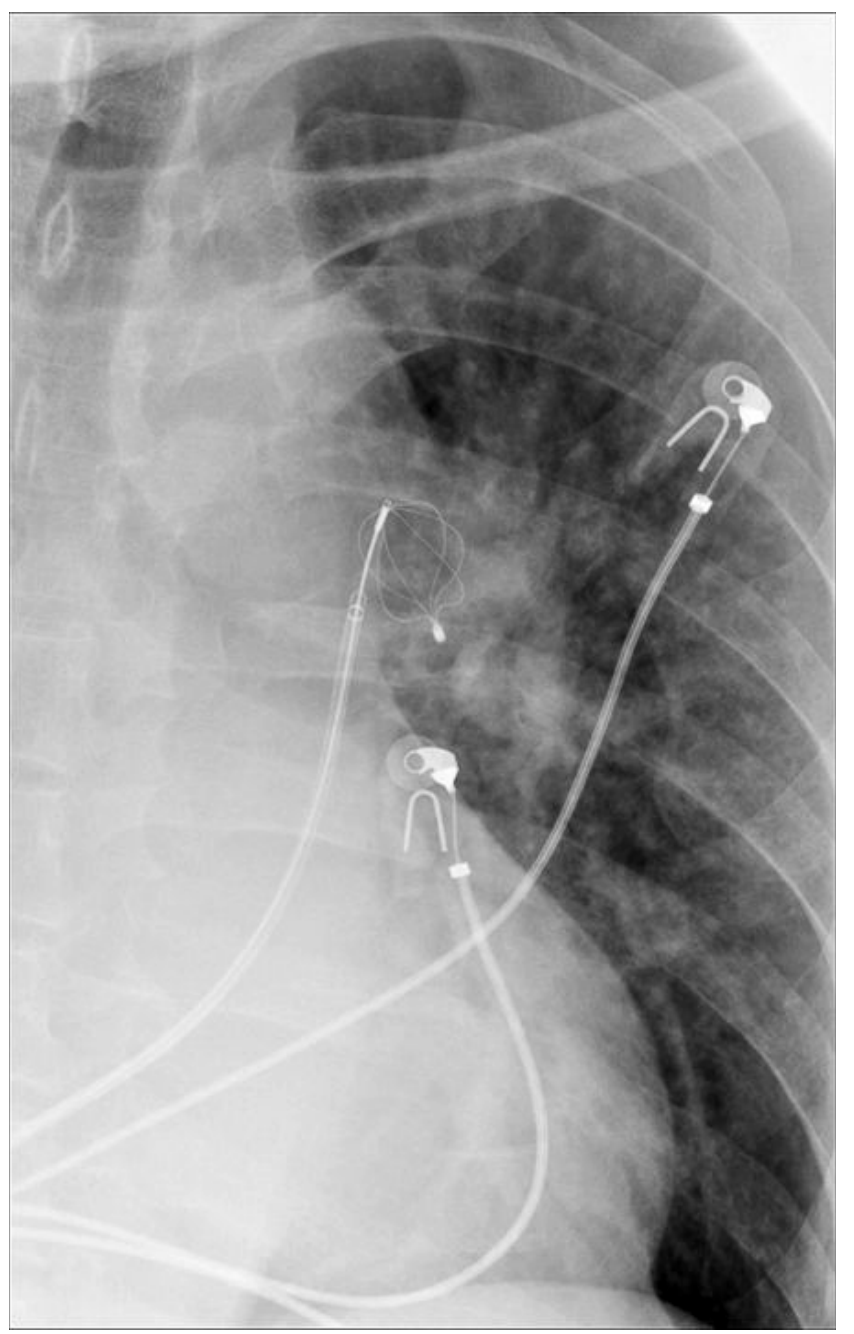

1. ábra

| Mechanikus thrombuseltávolítás a bal pulmonalis artériából
A súlyos masszív embolia intervenciós radiológiai katéteres kezelésekor elsősorban a súlyos hemodinamikai katasztrófahelyzeten kell enyhítenünk, amelyet a thrombusok darabolásával, mechanikus eltávolításával érhetünk el a leggyorsabban (1. és 2. ábra). A módszerrel a pulmonalis artériában a nyomást dramatikusan csökkenteni lehet, ami a terápia sikere szempontjából döntő az időnyerés miatt. A gyors nyomáscsökkentéssel érjük el, hogy a beteg ne halljon meg az akut első néhány órában. A thrombusdarabolást követő szelektív fibrinolitikus terápia feladata optimális esetben a tüdő érrendszerének thrombusmentessé tétele. A szelektív fibrinolízisnél nem elegendő a főbb erek thrombusmentessé tétele, törekedni kell a kapilláriskeringés helyreállítására is, a késői pulmonalis hypertensio és annak minden következménye kivédése céljából. A terápia időtartama ezért 12 órától akár 5 napig is eltarthat [4].

\section{Akut alsó végtagi mélyvénás thrombosisok kezelése}

Akut iliofemoralis mélyvénás thrombosis esetén intervenciós módszerekkel a thrombustömeg akár teljes egészében is eltávolítható, feloldható [6]. Ezáltal nemcsak a panaszok gyors csökkenése érhető el, hanem elkerülhető az egyébként a betegek több mint felénél hónapokkal, évekkel a thrombosis lezajlása után kialakuló postthromboticus szindróma is. Amennyiben az iliacaszintű thrombosis oka külső kompresszió (például May-Thurnerszindróma [bal vena iliaca communis kompresszió a jobb arteria iliaca communis által]), a thrombus feloldásával
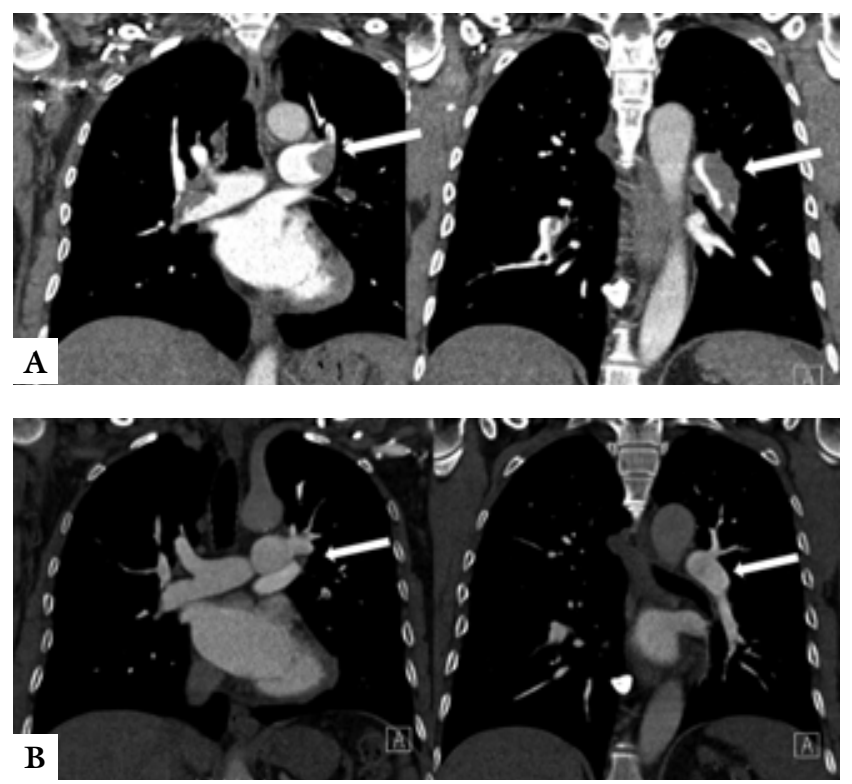

2. ábra

Komputertomográfiás pulmonalis angiográfia (CTPA) szelektív thrombolysis előtt és után. A) CTPA lysis előtt, masszív pulmonalis embolia. B) Kontroll-CTPA lysis után. Csaknem teljesen thrombusmentes pulmonalis artériák minimális, hemodinamikailag már jelentéktelen residualis telődési hiánnyal a bal lingularis artériában 
egy időben a szúkült szakasz stentelésének is meg kell történnie. A behatolási kapu helyét a thrombosis szintje határozza meg; leggyakrabban az azonos oldali vena poplitea felől történik az intervenció.

Az intervenciós thrombuseltávolításnak két fó fajtáját különböztetjük meg: az egyik a katéteres thrombolysis, a másik pedig a percutan mechanikus thrombectomia. Az utóbbit csaknem minden esetben katéteres thrombolysissel kombinálják, ezért farmakomechanikus thrombolysisnek is szokták nevezni. A percutan mechanikus thrombectomia önmagában, thrombolyticus szer adása nélkül, csak akkor alkalmazható, ha a thrombolysis abszolút kontraindikált. Bármelyik módját is választjuk azonban az intervenciónak, a betegek kiegészítésképpen antikoaguláns terápiában is kell, hogy részesüljenek.

\section{Katéteres thrombolysis}

Katéteres thrombolysis esetén egy speciális, több oldalnyílással rendelkező katétert vezetünk be néhány órára (napra) a thrombusba, így a thrombolyticus szer - a szisztémás thrombolysissel ellentétben - közvetlenül a thrombusban fejti ki a hatását, ráadásul ugyanazon hatás eléréséhez lényegesen kevesebb thrombolyticus szer adása is elegendő [7]. Nincs arra vonatkozó irodalmi adat, hogy melyik a legjobb thrombolyticus szer a katéteres lysishez; általában a rekombináns szöveti plazminogén aktivátort, ritkábban az urokinázt vagy sztreptokinázt alkalmazzák. A korai fibrinolitikus hatása az r-tPA-nak és a sztreptokináznak a leggyorsabb, ezért a költséghatékonyság növelése érdekében akár kombinálhatjuk is a szereket (például először sztreptokinázt adunk, aztán r-tPA-val folytatjuk a kezelést). A gyakorlatban azt tapasztaltuk, hogy a szisztémás r-tPA-kezelésre nem reagáló thrombusok a szelektív sztreptokinázkezelésre az esetek nagy százalékában általában teljesen feloldódtak.

\section{Percutan mechanikus thrombectomia}

A percutan mechanikus thrombectomia lehet rotációs, rheolyticus és ultrahangos. A rotációs percutan mechanikus thrombectomiáknak is több fajtája létezik. Míg az Aspirex (Straub Medical) lényege, hogy egy speciális, több oldalnyílású katétert helyeznek be a thrombusba, majd szívóhatásra kisebb-nagyobb thrombusdarabokat juttatnak a katéterbe, amelyet aztán az abban lévő és fo-

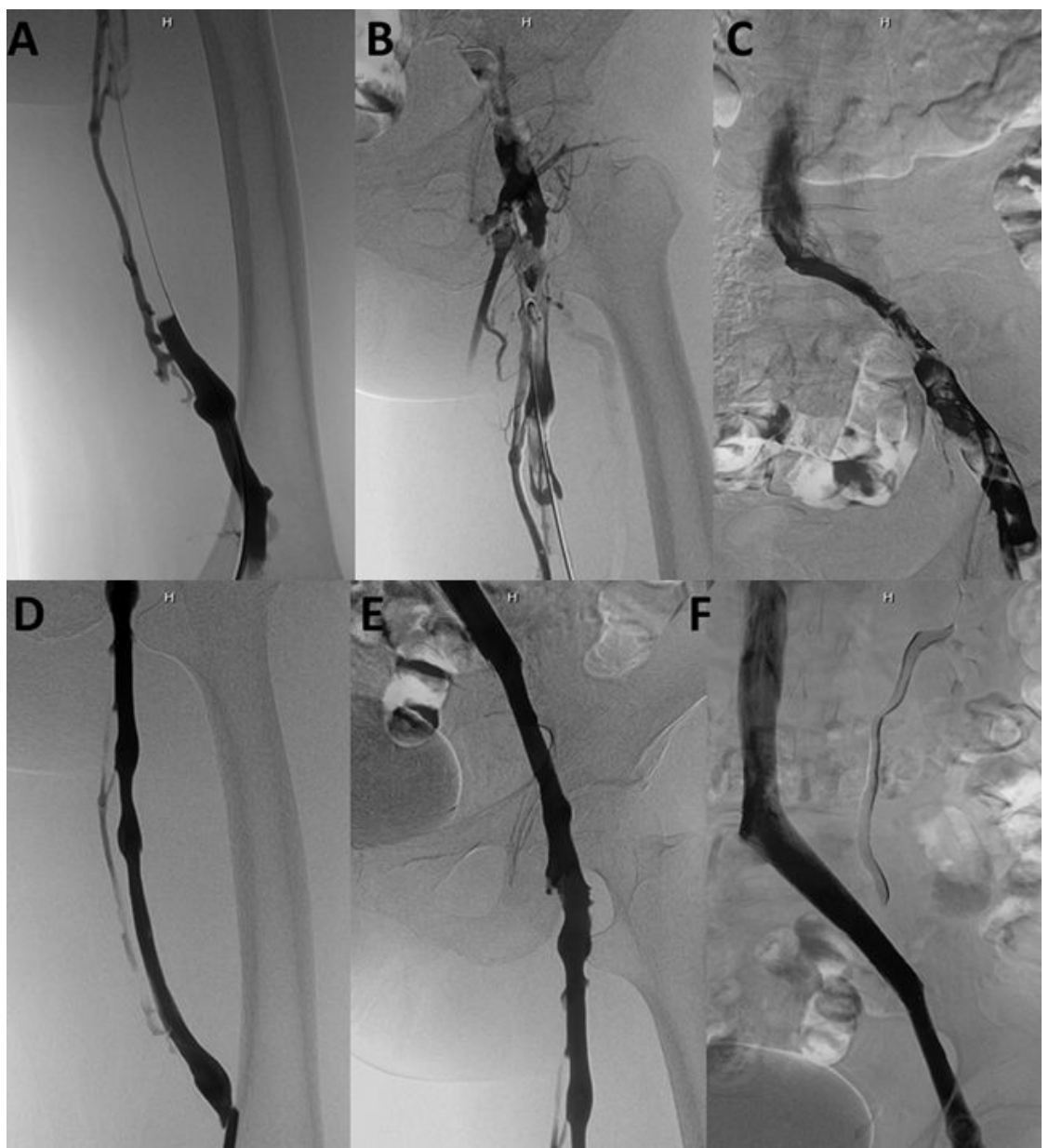


lyamatosan forgó fémspirál felaprít; addig a Trellis (Bacchus Vascular) lényege, hogy az eltávolítandó thrombus proximalis és distalis végénél egy-egy occlusiós ballont fújnak fel, majd a kettő közötti szakaszon lévő thrombusba thrombolyticus szert juttatnak, a thrombust fémspirállal felaprítják, végül katéterrel aspirálják.

A rheolyticus percutan mechanikus thrombectomia fiziológiás sóoldat „jet”-et használ a thrombus feldarabolásához (AngioJet, Medrad). A módszer hátránya, hogy haemolysist és haemoglobinuriát okoz. A haemolysis kálium- és adenozinfelszabadulással jár, ami pedig arrythmiákat okozhat.

Az ultrahangos percutan mechanikus thrombectomia (EKOS) során ultrahanggal - mint mechanikai rezgéssel - a feloldandó thrombustömegen repedéseket hoznak létre, elősegítve ezzel a thrombolyticus szer bejutását a thrombusba [8].

A thrombolysis mindkét formája - a katéteres thrombolysis és a farmakomechanikus thrombolysis is - hatékony módszer, azonban a farmakomechanikus thrombolysis a mesterségesen lényegesen megnövelt thrombusfelszín miatt kevesebb thrombolyticus szer adásával is gyorsabb eredményességgel jár, az intervenció után a beteg hamarabb otthonába bocsátható, ezért költséghatékonyabb, mint a thrombusroncsolás nélküli katéteres thrombolysis $[9,10]$.

A különböző percutan mechanikus thrombectomiák technikai sikerrátája hasonló, szövődményrátájuk pedig alacsony ( $0 \%$ halál, $<1 \%$ tüneteket adó tüdőembólia). A módszerek között egy lényeges különbség van, ez pedig az intervenció időtartama. Addig, amíg például a thrombuseltávolítás az AngioJet rheolyticus percutan mechanikus thrombectomiával vagy a Trellis-féle rotációs percutan mechanikus thrombectomiával akár egy óra alatt is elvégezhető, addig az ultrahangos percutan mechanikus thrombectomia vagy a katéteres thrombolysis órákig vagy akár napokig is eltarthat [11].

Összefoglalásképpen elmondható, hogy az intervenciós thrombuseltávolítás nemcsak, hogy megakadályozza a postthromboticus szindróma kialakulását és a vénás thromboemboliás események ismételt bekövetkezését, hanem ezáltal hosszú távon költséghatékonyabb is, mint a standard antikoaguláns terápia.

\section{Az alsó végtagi mélyvénás szükületek kezelése}

$\mathrm{Az}$ artériák stentelésével ellentétben, a vénás stentelések létjogosultsága csak néhány évvel ezelőtt vált bizonyossá. Stentelés az iliofemoralis vénás szakaszon a következő obstrukciós komponenssel is bíró elváltozások esetén jön szóba: May-Thurner-szindróma, egyidejű krónikus iliacalis occlusio és akut iliofemoralis mélyvénás thrombosis, krónikus vénás elégtelenség, postthromboticus szindróma, vénás stasis stb. Mivel a vénás rendszer nagyon sok tekintetben más, mint az artériás, ennek megfelelően új típusú öntáguló nitinolstentek kerültek kifejlesztésre
(Zilver Vena [Cook Medical], Sinus-Venus [Optimed], Veniti Vici [Veniti Medical]). Általánosságban igaz, hogy a vénás stentek nagyobb átmérőjüek, hosszabbak, nagyobb radiális erejüek és flexibilisebbek, mint az artériás stentek. A kezdeti klinikai eredmények a Zilver Vena és a Sinus-Venus stentek használata kapcsán biztatóak: implantációjuk kevés szövődménnyel jár, nyitva maradási rátájuk pedig magas (3. ábra) [12].

\section{Következtetések}

A vénás betegségek kezelésében az intervenciós radiológia számos kis sebzéssel járó, hatékony módszerrel rendelkezik, amelyek rövidebb ápolási idővel, kevesebb kellemetlenséggel, gyors felépüléssel, esetenként jobb kozmetikai eredménnyel járnak, mint a nyitott sebészeti beavatkozás. A módszerek egy része nem helyettesíthető más gyógyítóeljárással, és sürgősségi esetekben több esetben életmentő lehet. Az egyre jobb és sikeres onkológiai kezelések miatt gyakoribbak a terápia szövődményeként fellépő vénás szúkületek, amelyek növelik az intervenciós radiológiai módszerek jelentőségét. A szelektív módszerekkel nemcsak a késóbbi funkciót (például vénabillentyü-elégtelenség kialakulásának megakadályozása) lehet megóvni, hanem gyors és költséghatékony is a kezelés teljes vertikuma szempontjából. Az intervenciós radiológiai centrumok létrehozásával reméljük, hogy ez a gyakorlati tudás mielőbb széles körben a betegeink szolgálatába állítható.

Anyagi támogatás: A közlemény megírása anyagi támogatásban nem részesült.

Szerzôi munkamegosztás: A cikk elkészültéhez B. I., D. E. 40-40\%-ban, H. Z. 20\%-ban járult hozzá. A cikk végleges változatát valamennyi szerző elolvasta és jóváhagyta.

Érdekeltségek: A szerzőknek nincsenek érdekeltségeik.

\section{Irodalom}

[1] Skaf, E., Stein, P. D., Beemath, A., et al.: Fatal pulmonary embolism and stroke. Am. J. Cardiol., 2006, 97(12), 1776-1777.

[2] Stein, P. D., Beemath, A., Meyers, F. A., et al.: Pulmonary embolism as a cause of death in patients who died with cancer. Am. J. Med., 2006, 119(2), 163-165.

[3] Sándor, T.: New perspectives in thrombosis prevention. [Új távlatok a trombózisprofilaxisban.] Érbetegségek, 2011, 18(1), 13-18. [Hungarian]

[4] Battyány, I., Horváth, L., Sárosi, I., et al.: Local fibrinolytic treatment in subtotal pulmonary embolism. [Lokális fibrinolytikus kezelés subtotalis tüdőembóliában.] Orv. Hetil., 1999, 140(16), 873-879. [Hungarian]

[5] Sárosi, I., Mübl, D., Bogár, L., et al.: Treatment possibilities for extensive pulmonary embolism as an alternative to the Trendelenburg operation. [Nagy kiterjedésű tüdőembóliák kezelési lehetőségei, mint a Trendelenburg-mútét alternatívái.] Orv. Hetil., 1995, 136(47), 2553-2559. [Hungarian] 
[6] Haig, Y., Enden, T., Slagsvold, C. E., et al.: Determinants of early and long-term efficacy of catheter-directed thrombolysis in proximal deep vein thrombosis. J. Vasc. Interv. Radiol., 2013, 24(1), $17-24$.

[7] Szatmári, F., Paukovics Á., Bartek, P., et al.: Novel possibility for the treatment of deep vein thrombosis. [Új lehetőség a mélyvénás trombózis kezelésében.] Érbetegségek, 1999, 6(4), 119124. [Hungarian]

[8] Kennedy, R. J., Kenney, H. H., Dunfee, B. L.: Thrombus resolution and hemodynamic recovery using ultrasound-accelerated thrombolysis in acute pulmonary embolism. J. Vasc. Interv. Radiol., 2013, 24(6), 841-848.

[9] Lin, P. H., Zhou, W., Dardik, A., et al.: Catheter-direct thrombolysis versus pharmacomechanical thrombectomy for treatment of symptomatic lower extremity deep venous thrombosis. Am. J. Surg., 2006, 192(6), 782-788.
[10] Kim, H. S., Patra, A., Paxton, B. E., et al.: Adjunctive percutaneous mechanical thrombectomy for lower-extremity deep vein thrombosis: clinical and economic outcomes. J. Vasc. Interv. Radiol., 2006, 17(7), 1099-1104.

[11] Karthikesalingam, A., Young, E. L., Hinchliffe, R. J., et al.: A systematic review of percutaneous mechanical thrombectomy in the treatment of deep venous thrombosis. Eur. J. Vasc. Endovasc. Surg., 2011, 41(4), 554-565.

[12] O'Sullivan, G. J., Sheehan, J., Loban, D., et al.: Iliofemoral venous stenting extending into the femoral region: initial clinical experience with the purpose-designed Zilver Vena stent. J. Cardiovasc. Surg. (Torino), 2013, 54(2), 255-261.

(Battyáni István dr., Pécs, Ifjúság útja 13., 7624 e-mail: batyo@chello.hu)

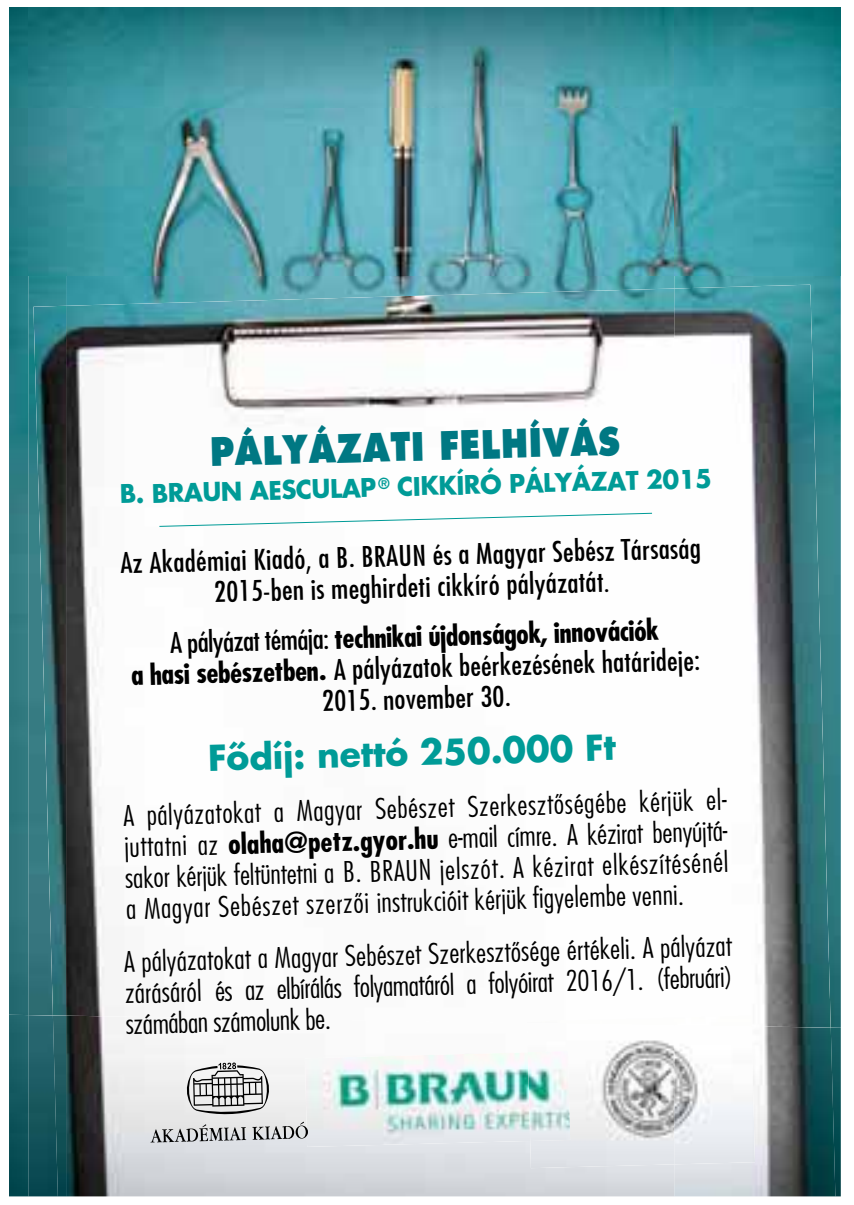

\section{Pिx}

\section{Minóségi sugárvédelem}

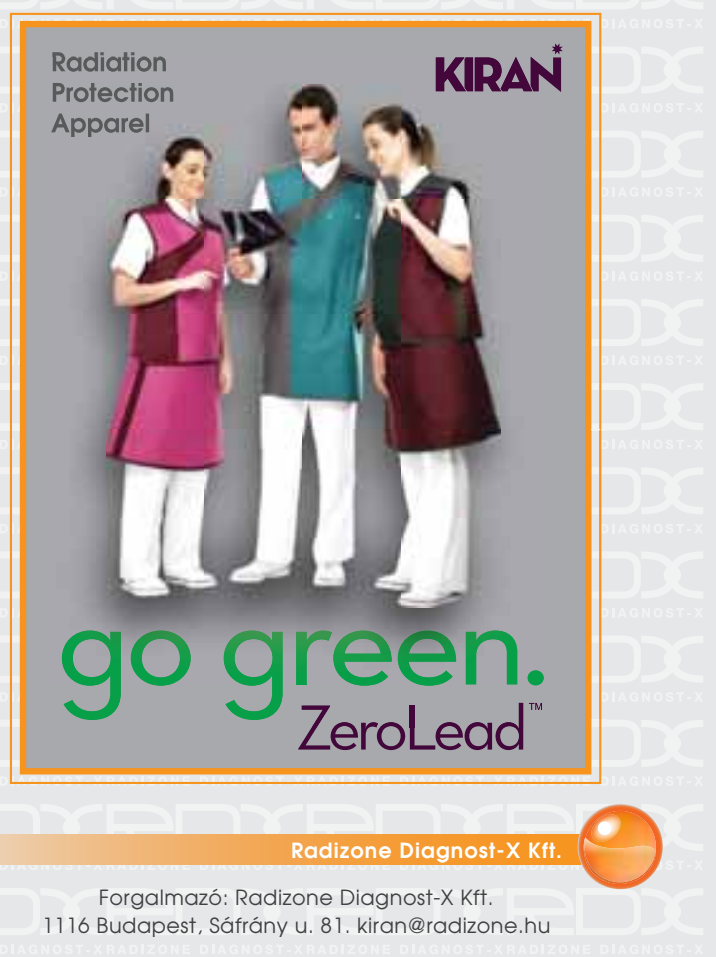

